\title{
Model of Environmental Problems Priority Arising from the use of Environmental and Natural Resources in Machinery Sectors of Thailand
}

\author{
Pruethsan SUTTHICHAIMETHEE*, Yothin SAWANGDEE
}

\begin{abstract}
Institute for Population and Social Research, Mahidol University, Salaya, Phutthamonthon, Nakhonpathom, Phutthamonthon Sai 4 Rd., Salaya, Phutthamonthon, Nakhornpathom,Thailand. 73170, Thailand
\end{abstract}

\begin{abstract}
The objective of this research is to propose an indicator to evaluate environmental impacts from the Machinery sectors of Thailand, leading to more sustainable consumption and production in this sector of the economy. The factors used to calculate the Forward Linkage, Backward Linkage and Real Benefit were the Total Environmental Costs. The highest total environmental cost was Railway Equipment which needs to be resolved immediately because it uses natural resources more than its carrying capacity, higher environmental cost than standard, and contributes low real benefit. Electric Accumulator \& Battery, Secondary Special Industrial Machinery, Motorcycle, Bicycle \& Other Carriages, and Engines and Turbines need to be monitored closely because they are able to link to other production sectors more than any other production sectors do, and they have high environmental cost. To decide a sustainable development strategy of the country, therefore, results of this research must be used to support decision-making.
\end{abstract}

Keywords - Machinery sectors; Environment cost; Carrying capacity; Forward linkage; Backward linkage

\section{INTRODUCTION}

Thailand's economy has been rapidly developed, and it was found that Machinery industry has been expanding continuously, rising from $2.74 \%$ in 1999 to $33.79 \%$ in 2014. As a result, the Gross Domestic Product (GDP) per capita has been constantly increasing as shown in Figure 1 [1] and the urban area continues to grow. Furthermore, the tourism industry has expanded together with the Machinery industry. It gives the advantage to the economy of the country, which currently has improved because the amount of capital steadily flows into the economy. Moreover, many investors from other countries invested in Thailand, which is the rationale for the rise in the economy of this country [2]. However, businesses and consumers are major players in the economic system [3]. Consumers want to gain high utilization under limited budgets, whereas businesses aim to maximize their profits and reduce expenditures [4], [5]. Neither party seems to pay attention to environmental cost, causing over-consumption and overproduction [2]. After all, the sustainable development for the country should be created in three dimensions, collectively [6], namely economic, social, and environmental. Previously, Thailand gave priority to developing only economic growth. Furthermore, the National Economic and Social Development Board [2015] stated that firms did not consider the cost from natural resources materials, energy and transportation, fertilizer and pesticides, and sanitary and similar services, which represent environmental costs. As a result, Thailand did not achieve sustainable development because economic growth usually goes together with higher environmental cost [7].

\footnotetext{
* Corresponding author.

E-mail address: pruethsan@gmail.com

(C2016 Pruethsan Sutthichaimethee, Yothin Sawangdee. This is an open access article licensed under the Creative Commons Attribution

License (http://creativecommons.org/licenses/by/4.0), in the manner agreed with De Gruyter Open.
} 


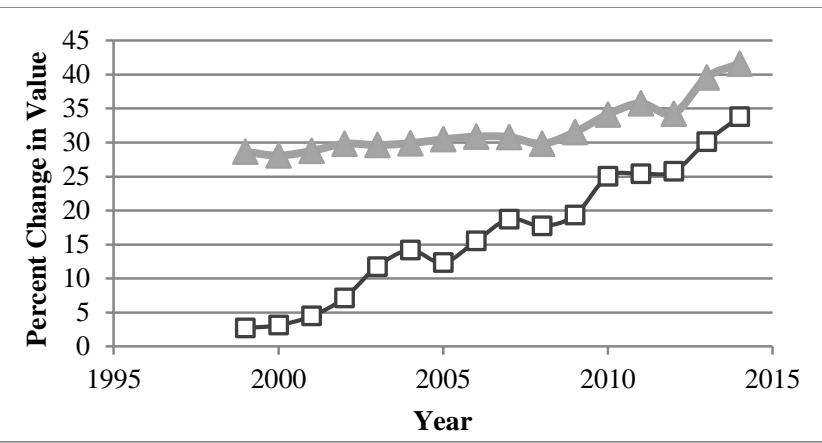

Fig. 1. Relationship between changing rate of Machinery industry (percentage) and the ratio of production to GDP (percentage).

Figure 1 indicates that the Machinery sector represents the major occupations of many people in Thailand, and it consistently generates high income in the country [8]. This can present the fact that, since the Machinery sector has continuously increased along with the GDP of the country, Thailand's economy will also constantly develop. At the same time, the Asian Development Bank [2015] found that the Machinery sector has been using environmental and natural resources at an increasingly high rate compared with other sectors of the economy. Thus, the government must give increased attention to managing environmental problems caused by the Machinery sector because this production sector influences the economic growth of the country [1], [2]. Moreover, the government should prioritize its efforts by considering the income and cost of economic sectors in proportion to their scale. Finally, they should prepare solutions to deal with problems and trends that might occur in the future [1], [8].

Accordingly, the formulation of policy and strategies to develop the country must concern Real Benefit and Total Environmental Costs in the three areas mentioned above [8]. Likewise, prioritization of environmental problems should be clearly defined [2], [9]. All of these factors could be included in an index to indicate environmental problems and lead to sustainable solutions in the future, which is the main emphasis of this research.

\subsection{Objectives}

To propose an indicator to evaluate environmental impacts from the Machinery sector of Thailand, leading to more sustainable consumption and production in this sector of the economy.

\subsection{Scope of Study}

1. Environmental and natural resource costs are calculated for each Machinery sectors using data from Thailand's Input-Output Table. The calculation uses input data categorized as natural resource materials, energy and transportation, fertilizer and pesticides, and sanitary and similar services. The effects from consumption of the services are not included in environmental cost.

2. The main calculations in this study were done with data from the Input-Output Table of Thailand for 2015, which were the most current data. The precision of the calculations was limited by economic and social descriptions used to create the Input-Output Table.

\subsection{Conceptual Framework}

The conceptual framework (Fig. 2) for selection of product sectors for evaluating their Shadow Environmental Cost is based on aims and concepts of sustainable development [1]. Three supporting concepts are Welfare Economics of A. C. Pigou [2], [10], Natural Resource Economics and Ecology Economics [11]. 


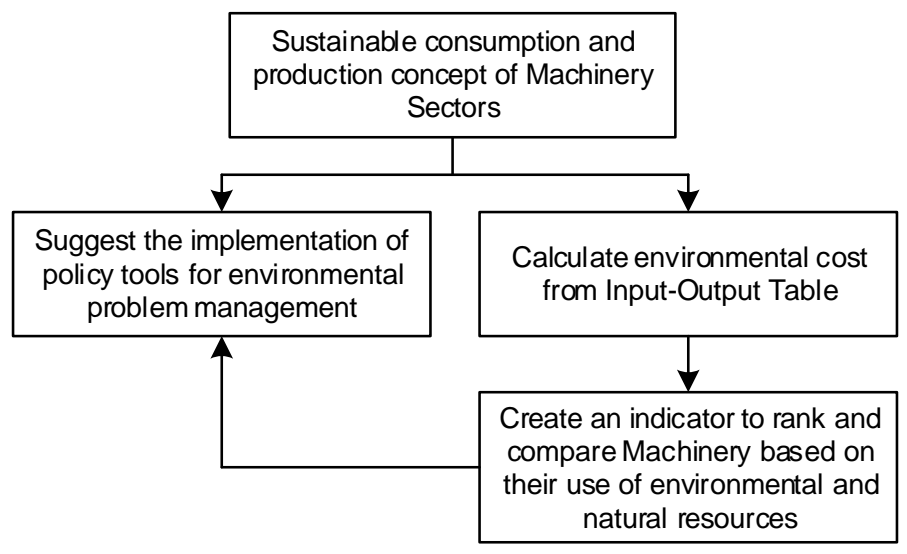

Fig. 2. Conceptual Framework.

\section{Materials ANd Methods}

The model in this study is related to the Input-Output Table, in which the relationships of the data were categorized by rows and columns as follows in Table 1 [12].

Rows present output distribution of product sector $i$ for $n$ product sectors and the Gross product of product sector $i$ can be defined, for $1 \leq i \leq n$, by

$$
X_{i}=\sum_{j=1}^{n} X_{i j}+F_{i}
$$

where

$X_{i}$ refers to Gross product of product sector $i,{ }_{i j}$ refers to product distribution of product sector $i$ of goods and services production for product sector $j$, and $F i$ refers to the final demand of product sector $i$.

Columns show the structure of expense or cost of goods production for product sector $j(X i)$ that could be defined, for $1 \leq j \leq n$, by

$$
X_{i}=\sum_{j=1}^{n} X_{i j}+V_{j}
$$

where

$V_{j}$ refers to value added of product sector $j$, only if input value is directly proportional to output value. Then $X_{i j}$ can be defined by the relationship of output $(X)$, input coefficient $(A)$ and final demand $(F)$ of production structure for an economic system that can be defined by

$$
\begin{gathered}
X=A X+F \\
X=[I-A]^{-1} F
\end{gathered}
$$

$[I-A]^{-1}$ is the Leontief Inverse Matrix (or inverse matrix) [17], which is important for economic system analysis when using the Input-Output table. The inverse matrix acts as a direct and indirect input coefficient of a production supply chain that could be used for supply chain 
length and intensity calculation. Environmental Cost of the production of each good or service can be calculated using the multiplication of the Environmental Cost coefficient and the inverse matrix. Finally, the result represents the total effect of a supply chain by giving the accumulated Environmental Cost of each good produced. The result also shows intensity of backward environmental effects of direct and indirect inputs and outputs. Furthermore, the result presents names, sectors and intensities of Environmental Costs that are useful to formulate an efficient policy and in environmental problem solving [5], [13].

Relationships in the Input-Output Table affect the output of each product sector $(\Delta \mathrm{F})$, which is called the Multiplier for Final goods and services. Equation (5) presents the calculation of the Multiplier.

$$
\Delta X=[I-A]^{-1} \Delta F
$$

If final demand $(\Delta \mathrm{F})$ increases, Environmental Cost will increase $(\Delta \mathrm{E})$. Equation (6) calculates the increase of Environmental Cost.

$$
\Delta E=R[I-A]^{-1} \Delta F
$$

From Table 1 to analyze the indicator to evaluate environmental impacts from the Machinery sector of Thailand, Equation (6) demonstrates the way Environmental costs could be calculated. The equation can be used to determine the indicator in measuring the level of environmental problems. This can be examined by comparing the environmental cost occurred in an industry with Average carrying capacity value. If the cost for a particular industry is lower than the average carrying capacity value, there is further capacity for production. Environmental cost values that are higher than the average carrying capacity value signify that there is no further capacity for production.

\begin{tabular}{|c|c|c|c|c|c|c|c|c|}
\hline \multirow{2}{*}{\multicolumn{2}{|c|}{ Using Sector }} & \multicolumn{2}{|c|}{ Processing Sectors } & & \multirow{2}{*}{\multicolumn{3}{|c|}{ Final demand }} & \multirow{3}{*}{$\begin{array}{c}\begin{array}{c}\text { Total } \\
\text { Outputs } \\
(\mathrm{X})\end{array} \\
x_{1} \\
\end{array}$} \\
\hline & & \multirow{2}{*}{$\begin{array}{c}1 \\
x_{11} \\
\end{array}$} & \multirow{2}{*}{$\frac{2}{x_{12}}$} & & & & & \\
\hline \multirow{2}{*}{$\begin{array}{c}\text { Processing } \\
\text { Sectors }\end{array}$} & 1 & & & $c_{1}$ & $i_{1}$ & $g_{1}$ & $e_{1}$ & \\
\hline & 2 & $x_{21}$ & $x_{22}$ & $c_{2}$ & $i_{2}$ & $g_{2}$ & $e_{2}$ & $x_{2}$ \\
\hline \multirow[t]{3}{*}{$\begin{array}{c}\text { Payments } \\
\text { Sectors }\end{array}$} & $\begin{array}{l}\text { Value } \\
\text { added }\end{array}$ & $l_{1}$ & $l_{2}$ & $l_{c}$ & $l_{1}$ & $l_{g}$ & $l_{e}$ & $\mathrm{~L}$ \\
\hline & & $n_{1}$ & $n_{2}$ & $n_{c}$ & $n_{1}$ & $n_{g}$ & $n_{e}$ & $\mathrm{~N}$ \\
\hline & Imports & $m_{1}$ & $m_{2}$ & $m_{c}$ & $m_{1}$ & $m_{g}$ & $m_{e}$ & $\mathrm{M}$ \\
\hline \multicolumn{2}{|c|}{ Total Outlays (X') } & $x_{1}$ & $x_{2}$ & $\mathrm{C}$ & $\mathrm{I}$ & $\mathrm{G}$ & $\mathrm{E}$ & $\mathrm{X}$ \\
\hline
\end{tabular}

TABLE 1. MATRIX USED to CREATE THE INPUT-OUTPUT TABLE OF PRODUCTION SECTORS

\section{RESUlts AND Discussion}

The results of the Environmental Costs, Real Benefit, and Forward Linkage are classified by each category of the production. This research can be summarized as following:

Table 2 lists the top ten Machinery sectors in terms of Forward Linkage, Backward Linkage, Real Benefit, Natural Resource Materials, Energy and Transportation, Fertilizer and Pesticides, and Sanitary and Similar Services. Real Benefit is the revenue for a sector, minus the environmental costs. The average Real Benefit was 0.871. If the Real Benefit for a given industry is lower than the average, it can be considered to represent a loss, while values higher than the average represent profit. The average value for environmental cost in Natural Resource Materials was 0.015; for Energy and Transportation, 0.07; for Fertilizer and Pesticides, 0.011; and for Sanitary and Similar Services, 0.0012. If the cost for a particular industry is lower than the average, there is further capacity for production. Environmental cost values that are higher than the average signify that there is no further capacity for production. 
TABLE 2. TOP TEN MACHINERY SECTORS RANKED By ForWARd LinKAge, REAL BENEFIT, AND ENVIRONMENTAL COST

\begin{tabular}{|c|c|c|c|c|c|c|c|c|c|c|c|c|c|}
\hline \multicolumn{2}{|c|}{ Forward Linkage } & \multicolumn{2}{|c|}{ Backward Linkage } & \multicolumn{2}{|c|}{ Real Benefit } & \multicolumn{2}{|c|}{$\begin{array}{l}\text { Natural Resource } \\
\text { Materials }\end{array}$} & \multicolumn{2}{|c|}{$\begin{array}{l}\text { Energy and } \\
\text { Transportation }\end{array}$} & \multicolumn{2}{|c|}{$\begin{array}{l}\text { Fertilizer and } \\
\text { Pesticides }\end{array}$} & \multicolumn{2}{|c|}{$\begin{array}{l}\text { Sanitary and } \\
\text { Similar Services }\end{array}$} \\
\hline value & sector & value & sector & value & sector & value & sector & value & sector & value & sector & value & sector \\
\hline 0.59 & $\begin{array}{l}\text { Railway } \\
\text { Equipment }\end{array}$ & 0.97 & $\begin{array}{l}\text { Electric } \\
\text { Accumulator } \\
\text { \& Battery }\end{array}$ & 0.54 & $\begin{array}{l}\text { Ship } \\
\text { Building }\end{array}$ & 0.025 & $\begin{array}{l}\text { Railway } \\
\text { Equipment }\end{array}$ & 0.158 & $\begin{array}{l}\text { Railway } \\
\text { Equipment }\end{array}$ & 0.027 & $\begin{array}{l}\text { Electric } \\
\text { Accumulator } \\
\text { \& Battery }\end{array}$ & 0.002 & $\begin{array}{l}\text { Household } \\
\text { Electrical } \\
\text { Appliances }\end{array}$ \\
\hline 0.55 & $\begin{array}{l}\text { Motorcycle, } \\
\text { Bicycle \& } \\
\text { Other } \\
\text { Carriages }\end{array}$ & 0.89 & $\begin{array}{l}\text { Special } \\
\text { Industrial } \\
\text { Machinery }\end{array}$ & 0.47 & $\begin{array}{l}\text { Repairing of } \\
\text { Motor } \\
\text { Vehicle }\end{array}$ & 0.019 & $\begin{array}{l}\text { Electric } \\
\text { Accumulator } \\
\text { \& Battery }\end{array}$ & 0.095 & $\begin{array}{l}\text { Agricultural } \\
\text { Machinery }\end{array}$ & 0.020 & $\begin{array}{l}\text { Railway } \\
\text { Equipment }\end{array}$ & 0.001 & $\begin{array}{l}\text { Electrical } \\
\text { Industrial } \\
\text { Machinery }\end{array}$ \\
\hline 0.53 & $\begin{array}{l}\text { Other } \\
\text { Electrical } \\
\text { Apparatuses } \\
\text { \& Supplies }\end{array}$ & 0.73 & $\begin{array}{l}\text { Motorcycle, } \\
\text { Bicycle \& } \\
\text { Other } \\
\text { Carriages }\end{array}$ & 0.45 & $\begin{array}{l}\text { Agricultural } \\
\text { Machinery }\end{array}$ & 0.017 & $\begin{array}{l}\text { Wood and } \\
\text { Metal } \\
\text { Working } \\
\text { Machinery }\end{array}$ & 0.090 & $\begin{array}{l}\text { Special } \\
\text { Industrial } \\
\text { Machinery }\end{array}$ & 0.019 & $\begin{array}{l}\text { Repairing of } \\
\text { Motor } \\
\text { Vehicle }\end{array}$ & 0.001 & $\begin{array}{l}\text { Motorcycle, } \\
\text { Bicycle \& } \\
\text { Other } \\
\text { Carriages }\end{array}$ \\
\hline 0.52 & $\begin{array}{l}\text { Engines and } \\
\text { Turbines }\end{array}$ & 0.53 & $\begin{array}{l}\text { Engines and } \\
\text { Turbines }\end{array}$ & 0.43 & $\begin{array}{l}\text { Special } \\
\text { Industrial } \\
\text { Machinery }\end{array}$ & 0.017 & $\begin{array}{l}\text { Ship } \\
\text { Building }\end{array}$ & 0.087 & $\begin{array}{l}\text { Ship } \\
\text { Building }\end{array}$ & 0.000 & Aircraft & 0.001 & $\begin{array}{l}\text { Radio and } \\
\text { Television }\end{array}$ \\
\hline 0.52 & $\begin{array}{l}\text { Ship } \\
\text { Building }\end{array}$ & 0.46 & $\begin{array}{l}\text { Office and } \\
\text { Household } \\
\text { Machinery }\end{array}$ & 0.43 & $\begin{array}{l}\text { Motorcycle, } \\
\text { Bicycle \& } \\
\text { Other } \\
\text { Carriages }\end{array}$ & 0.014 & $\begin{array}{l}\text { Other } \\
\text { Electrical } \\
\text { Apparatuses } \\
\text { \& Supplies }\end{array}$ & 0.086 & $\begin{array}{l}\text { Electric } \\
\text { Accumulator } \\
\text { \& Battery }\end{array}$ & 0.000 & $\begin{array}{l}\text { Ship } \\
\text { Building }\end{array}$ & 0.001 & $\begin{array}{l}\text { Electric } \\
\text { Accumulator } \\
\text { \& Battery }\end{array}$ \\
\hline 0.48 & $\begin{array}{l}\text { Repairing } \\
\text { of Motor } \\
\text { Vehicle }\end{array}$ & 0.45 & $\begin{array}{l}\text { Radio and } \\
\text { Television }\end{array}$ & 0.43 & $\begin{array}{l}\text { Insulated } \\
\text { Wire and } \\
\text { Cable }\end{array}$ & 0.014 & $\begin{array}{l}\text { Household } \\
\text { Electrical } \\
\text { Appliances }\end{array}$ & 0.085 & $\begin{array}{l}\text { Motorcycle, } \\
\text { Bicycle \& } \\
\text { Other } \\
\text { Carriages }\end{array}$ & 0.000 & $\begin{array}{l}\text { Motorcycle, } \\
\text { Bicycle \& } \\
\text { Other } \\
\text { Carriages }\end{array}$ & 0.001 & $\begin{array}{l}\text { Office and } \\
\text { Household } \\
\text { Machinery }\end{array}$ \\
\hline
\end{tabular}


$2016 / 17$

\begin{tabular}{|c|c|c|c|c|c|c|c|c|c|c|c|c|c|}
\hline \multicolumn{2}{|c|}{ Forward Linkage } & \multicolumn{2}{|c|}{ Backward Linkage } & \multicolumn{2}{|c|}{ Real Benefit } & \multicolumn{2}{|c|}{$\begin{array}{l}\text { Natural Resource } \\
\text { Materials }\end{array}$} & \multicolumn{2}{|c|}{$\begin{array}{l}\text { Energy and } \\
\text { Transportation }\end{array}$} & \multicolumn{2}{|c|}{$\begin{array}{l}\text { Fertilizer and } \\
\text { Pesticides }\end{array}$} & \multicolumn{2}{|c|}{$\begin{array}{l}\text { Sanitary and } \\
\text { Similar Services }\end{array}$} \\
\hline 0.46 & $\begin{array}{l}\text { Household } \\
\text { Electrical } \\
\text { Appliances }\end{array}$ & 0.43 & $\begin{array}{l}\text { Motor } \\
\text { Vehicle }\end{array}$ & 0.42 & $\begin{array}{l}\text { Engines and } \\
\text { Turbines }\end{array}$ & 0.013 & $\begin{array}{l}\text { Engines and } \\
\text { Turbines }\end{array}$ & 0.084 & $\begin{array}{l}\text { Engines and } \\
\text { Turbines }\end{array}$ & 0.000 & $\begin{array}{l}\text { Motor } \\
\text { Vehicle }\end{array}$ & 0.001 & $\begin{array}{l}\text { Other } \\
\text { Electrical } \\
\text { Apparatuses } \\
\text { \& Supplies }\end{array}$ \\
\hline 0.46 & $\begin{array}{l}\text { Motor } \\
\text { Vehicle }\end{array}$ & 0.40 & $\begin{array}{l}\text { Railway } \\
\text { Equipment }\end{array}$ & 0.41 & $\begin{array}{l}\text { Other } \\
\text { Electrical } \\
\text { Apparatuses } \\
\text { \& Supplies }\end{array}$ & 0.013 & $\begin{array}{l}\text { Motor } \\
\text { Vehicle }\end{array}$ & 0.080 & $\begin{array}{l}\text { Household } \\
\text { Electrical } \\
\text { Appliances }\end{array}$ & 0.000 & $\begin{array}{l}\text { Wood and } \\
\text { Metal } \\
\text { Working } \\
\text { Machinery }\end{array}$ & 0.001 & $\begin{array}{l}\text { Wood and } \\
\text { Metal } \\
\text { Working } \\
\text { Machinery }\end{array}$ \\
\hline 0.46 & $\begin{array}{l}\text { Agricultural } \\
\text { Machinery }\end{array}$ & 0.40 & $\begin{array}{l}\text { Agricultural } \\
\text { Machinery }\end{array}$ & 0.39 & $\begin{array}{l}\text { Electric } \\
\text { Accumulator } \\
\text { \& Battery }\end{array}$ & 0.012 & $\begin{array}{l}\text { Agricultural } \\
\text { Machinery }\end{array}$ & 0.079 & $\begin{array}{l}\text { Other } \\
\text { Electrical } \\
\text { Apparatuses } \\
\text { \& Supplies }\end{array}$ & 0.000 & $\begin{array}{l}\text { Insulated } \\
\text { Wire and } \\
\text { Cable }\end{array}$ & 0.001 & $\begin{array}{l}\text { Motor } \\
\text { Vehicle }\end{array}$ \\
\hline 0.46 & $\begin{array}{l}\text { Wood and } \\
\text { Metal } \\
\text { Working } \\
\text { Machinery }\end{array}$ & 0.40 & $\begin{array}{l}\text { Ship } \\
\text { Building }\end{array}$ & 0.38 & $\begin{array}{l}\text { Railway } \\
\text { Equipment }\end{array}$ & 0.011 & $\begin{array}{l}\text { Special } \\
\text { Industrial } \\
\text { Machinery }\end{array}$ & 0.076 & $\begin{array}{l}\text { Repairing of } \\
\text { Motor } \\
\text { Vehicle }\end{array}$ & 0.000 & $\begin{array}{l}\text { Household } \\
\text { Electrical } \\
\text { Appliances }\end{array}$ & 0.001 & $\begin{array}{l}\text { Agricultural } \\
\text { Machinery }\end{array}$ \\
\hline
\end{tabular}


Highlights from the findings include the following:

1. The highest Real Benefit in the Machinery sectors was Ship Building, while the lowest Real Benefit was Radio and Television. The lowest Real Benefit could signify loss in profit.

2. The highest Forward Linkage in the Machinery sectors was Railway Equipment, while the lowest Forward Linkage was Radio and Television.

3. The highest Backward Linkage in the Machinery sectors was Electric Accumulator \& Battery, while the lowest Backward Linkage was Aircraft.

4. The Machinery sectors with the highest environmental cost in terms of Natural Resource Materials was Railway Equipment. In contrast, the lowest environmental cost was Special Industrial Machinery. The cost indicator was above the average carrying capacity value including Railway Equipment, Electric Accumulator \& Battery, Wood and Metal Working Machinery, and Ship Building. This signifies that these sectors do not have capacity for further production. However, when analyzing sectors which have less indicator than the average carrying capacity value - Other Electrical Apparatuses \& Supplies, Household Electrical Appliances, Engines and Turbines, Motor Vehicle, Agricultural Machinery, and Special Industrial Machinery, it was found that these sectors have capacity in producing their products. This can be seen in Fig. 3 .

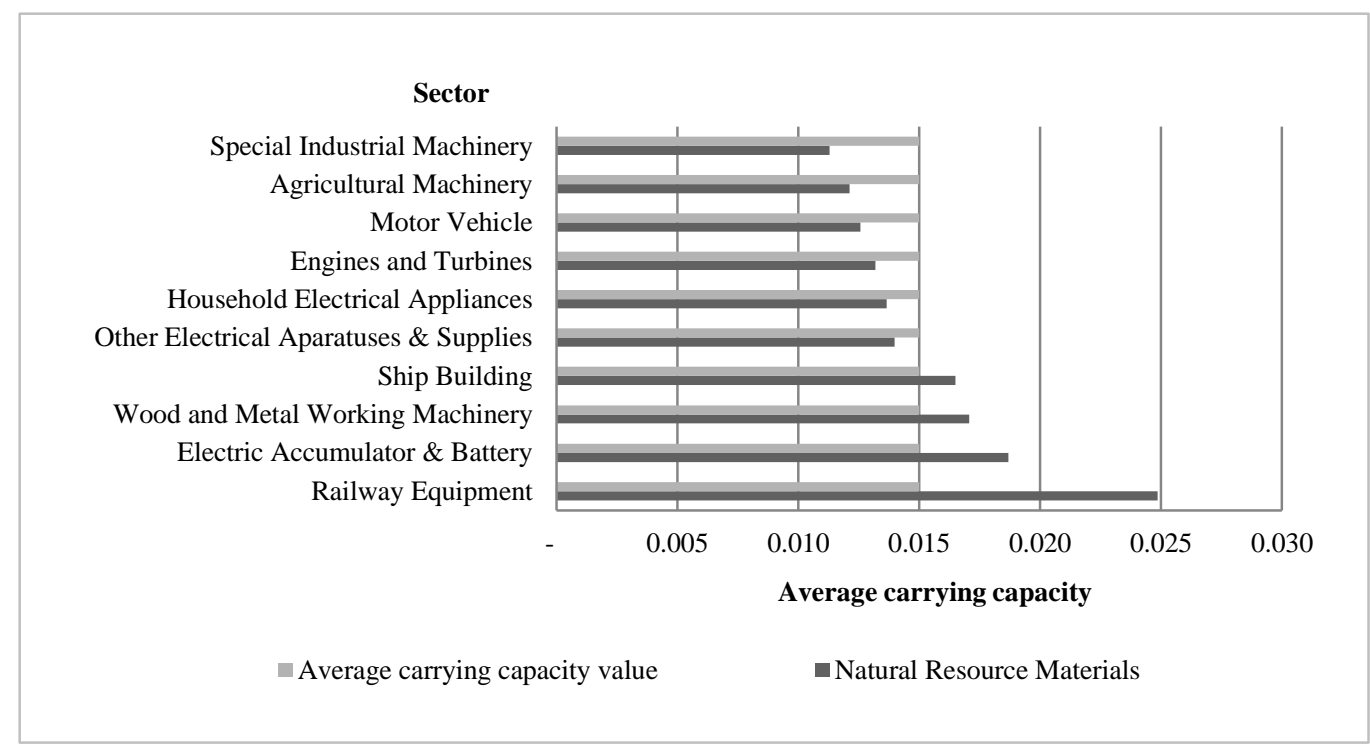

Fig. 3. Natural Resource Materials Cost.

5. The Machinery sectors with the highest environmental cost in terms of Energy and Transportation was Railway Equipment. In contrast, the lowest environmental cost was Repairing of Motor Vehicle. The cost indicators above the average carrying capacity value included Railway Equipment, Agricultural Machinery, Special Industrial Machinery, Ship Building, Electric Accumulator \& Battery, Motorcycle, Bicycle \& Other Carriages, Engines and Turbines, Household Electrical Appliances, Other Electrical Apparatuses \& Supplies, and Repairing of Motor Vehicle. This signifies that these sectors do not have capacity for further production. This can be seen in Fig. 4. 


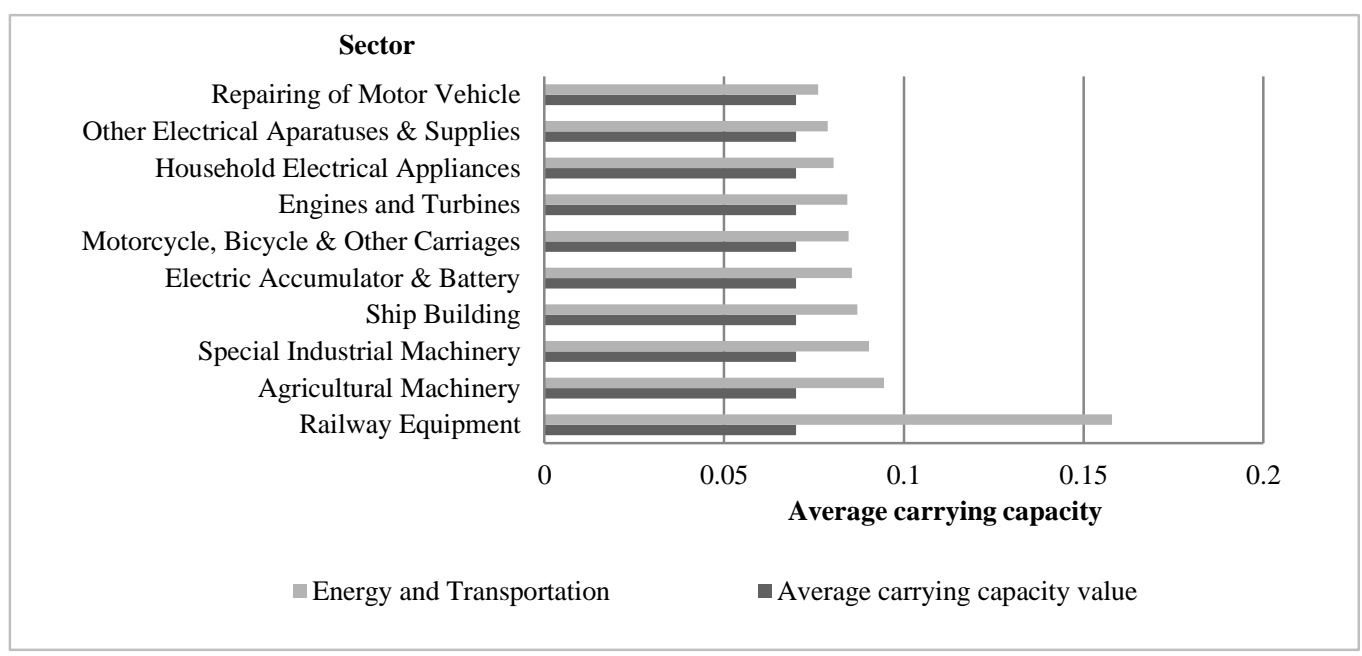

Fig. 4. Energy and Transportation Cost.

6. The Machinery sectors with the highest environmental cost in terms of Fertilizer and Pesticides was Electric Accumulator \& Battery. In contrast, the lowest environmental cost was Household Electrical Appliances. The cost indicator above the average carrying capacity value were Electric Accumulator \& Battery, Railway Equipment, and Repairing of Motor Vehicle. This signifies that these sectors do not have capacity for further production. However, when analyzing the sectors which have less indicator than the average carrying capacity value - Aircraft, Ship Building, Motorcycle, Bicycle \& Other Carriages, Motor Vehicle, Wood and Metal Working Machinery, Insulated Wire and Cable, and Household Electrical Appliances, it was found that these sectors have capacity in producing their products. This can be seen in Fig. 5.

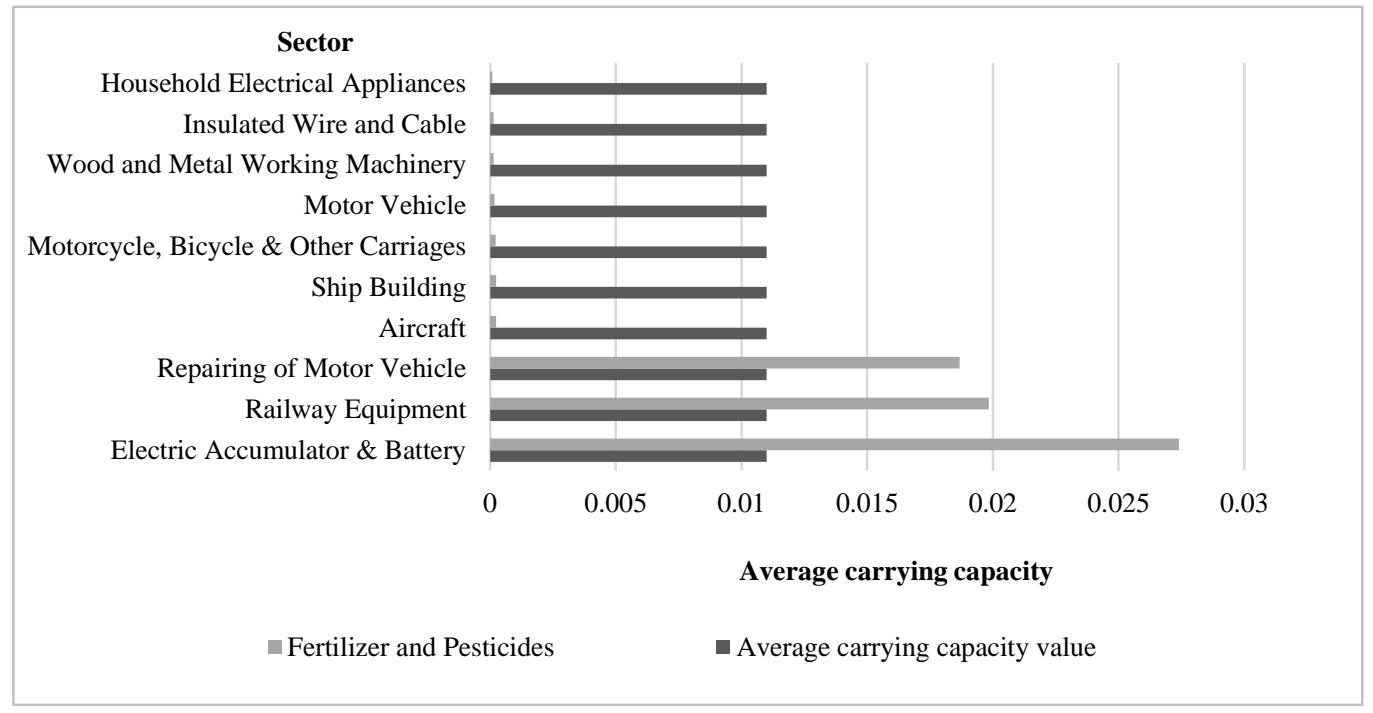

Fig. 5. Fertilizer and Pesticides Cost. 
7. The Machinery sectors with the highest environmental cost in terms of Sanitary and Similar Services was Household Electrical Appliances. In contrast, the lowest environmental cost was Agricultural Machinery. The cost indicators above the average carrying capacity value were Household Electrical Appliances. This signifies that these sectors do not have capacity for further production. However, when analyzing sectors which have less indicator than the average carrying capacity value - Electrical Industrial Machinery, Motorcycle, Bicycle \& Other Carriages, Radio and Television, Electric Accumulator \& Battery, Office and Household Machinery, Other Electrical Apparatuses \& Supplies, Wood and Metal Working Machinery, Motor Vehicle, and Agricultural Machinery, it found that these sectors have capacity in producing their products. This can be seen in Fig. 6 .

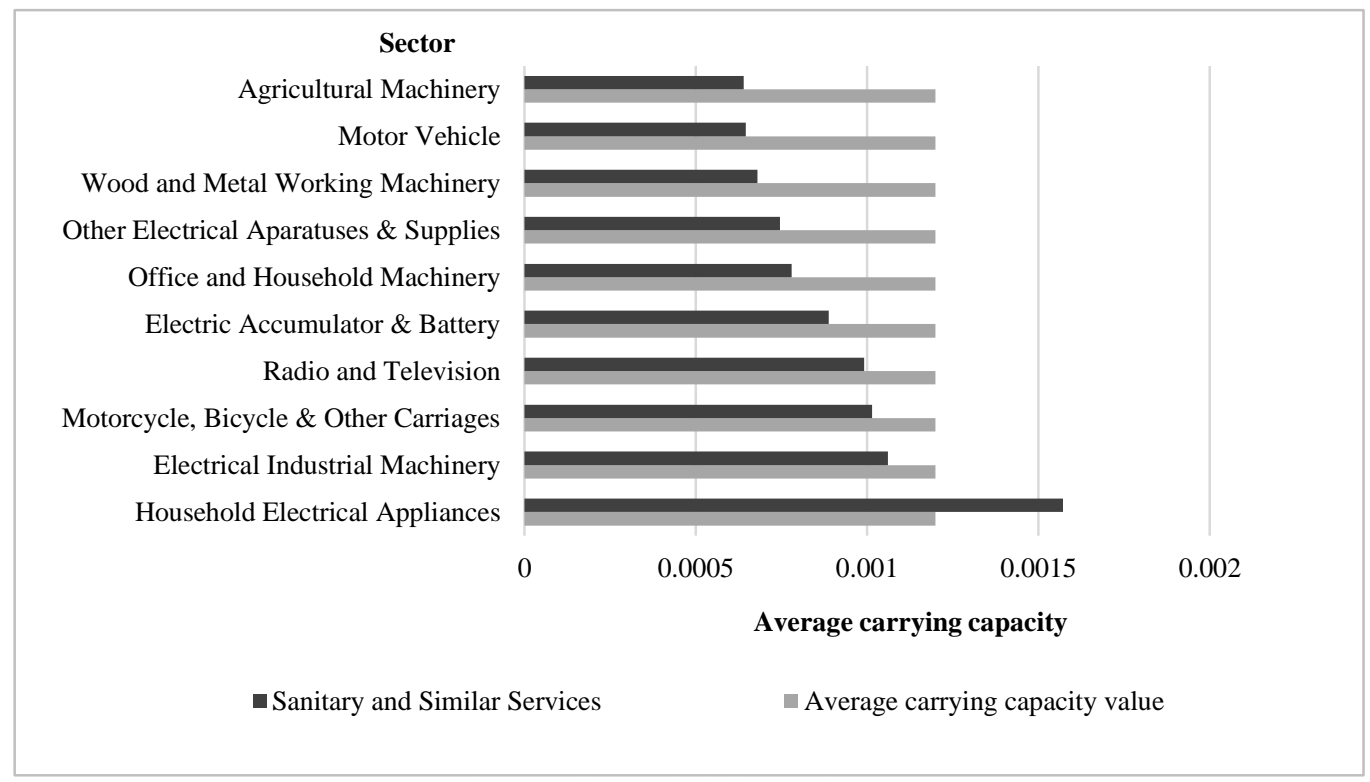

Fig. 6. Sanitary and Similar Services Cost.

This research is a pilot study on environmental costs of producing services in the economic system of Thailand, using the Input-Output database to account for differences among sectors. Environmental cost contributes damage to the environment and is affected by the behavior and decisions of producers, consumers, and the government. Environmental cost cannot be estimated from the activities occurring in the market alone. Instead, the estimation of the environmental cost of each production sector in Thailand needs to incorporate Shadow Environmental Cost, which reflects environmental cost. Information can be used to compare the environmental cost of production sectors, and could help to create an environmental problem management indicator. The Shadow Environmental Cost modeled in this study relies on four groups of economic data, including costs of Natural Resources Materials, Energy and Transportation, Fertilizer and Pesticides, and Sanitary and Similar Services.

The results of this examination of environmental costs by each sector is consistent with the research of Zhang Y. (2010), Pantavisid S. (2012), and the results of the Real Benefit analysis is also consistent with the research of Sa-nguanwongthong N. (2013), TDRI (2007), ADB (2014) which used the average value to create the environmental costs index [14], [15], [16]. From the research, it was found that when comparing the average and the result from the comparison, there were 18 sectors in environmental costs of natural resource material that had higher value than the cost of average criteria. Likewise, 16 sectors of energy and transportation, 5 sectors of 
fertilizer and pesticide, and 14 sectors of sanitary and similar service showed that the result from the research were higher than the average. Thus, in the past, Thailand was not interested in such environmental costs indicators, which led to damage of the environmental and natural resources because of overuse.

The highest environmental costs are Railway Equipment, Motorcycle, Bicycle \& Other Carriages, Agricultural Machinery, and Electric Accumulator \& Battery. They create negative impact on the environmental and natural resources. The government must reduce environmental cost and announce a protection scheme not to affect in the future, which should contain proactive and reactive strategy. Proactive strategy is to utilize eco-friendly input and process [Green Growth], while reactive strategy is to improve the law, especially Polluters Pays Principle [PPP], to perform effectively and efficiently with offenders [2], [17].

From the analysis, thus, Railway Equipment has the highest environmental problem. Moreover, it generates low revenue, which leads to low real benefit. This production sector must resolve the problem immediately because the calculated value was higher than standard value resulting in carrying capacity. Not only Railway Equipment that ought to be solved urgently, the other 9 sectors in sequence also need solutions. If the problems are not solved urgently, it is difficult to do so in the future and they contribute huge damage. When comparing environmental problems with Real benefit it was found that 10 problematic sectors did not give high Real benefit. Consequently, the government should pay attention to the agricultural and service sectors or other sectors because these generate high income to the country with low environmental cost. However, Thailand must monitor closely all sectors the have potential for environmental problems in the short term by looking at the environmental cost. All of them highly link to the economy and to over consumption of necessary environmental natural resources [18].

Thailand must monitor closely all sectors with potential to have environmental problems in the short term by seeing the Backward linkage value. The top 10 Backward linkage are Electric Accumulator \& Battery, Secondary Special Industrial Machinery, Motorcycle, Bicycle \& Other Carriages, Engines and Turbines, Office and Household Machinery, Radio and Television, Motor Vehicle, Railway Equipment, Agricultural Machinery, and Ship Building. All of them highly link to the economy and over consumption of necessary environmental natural resources [2], [19].

The results of this research could also be applied to environmental problem management under the sustainable production concept with a limitation of administrative resources. This leads to efficient environmental consumption by society [17], [20]. The classification of natural resources and environmental capital of the whole system can be implemented at the micro level [2], while the classification from Green Value Added and the Forward Linkage is for decision making at a macro level [1]. Consequently, using the correct data allows for efficient environmental problem-solving.

Thailand and other ASEAN countries have not created an environmental problem indicator using Real Benefit, environmental cost, and environmental problems, and this has led them to formulate ineffective policies and plans for their countries. More developed countries, like Japan and European countries, give importance to environmental stewardship, and their efforts can be reflected in higher Green GDP. This methodology would help Thailand formulate efficient policy and forecast future conditions more accurately, allowing the nation to deal with crises arising from environmental problems [9], [10]. 


\section{Conclusion}

The result from the four environmental cost analyses allows the researcher to form indicators which could help to identify the level of environmental problems. This can be considered by comparing the environmental cost with the Average carrying capacity value. If the cost for a particular industry is lower than the average carrying capacity value, there is further capacity for production. When environmental cost values are higher than the average carrying capacity value, it signifies that there is no further capacity for production. The results below are the summary of the comparison and suggestions.

Railway Equipment is the highest environmental problem and environmental cost that gives low Real benefit. Besides, they overly use environmental natural resources more than the carrying capacity. However, other nine production sectors also need to be solved immediately because all of them are also using environmental and natural resources more than the carrying capacity. Electric Accumulator \& Battery must be monitored closely. Railway Equipment has the highest environmental cost. The government must find a solution to reduce such cost in order to increase Real benefit, which is advantageous to Thailand. In the past, Thailand did not give importance to environmental cost, thus leading to economic crisis which re-occur and which last a long time. Consequently, the result of this operation can be used to support economic planning of the country and management guideline for the country.

\section{ACKNOWLEDGEMENT}

This work was performed with the approval of the Burapha University and the Office of the National Economic and Social Development Board.

\section{CONFLICT OF INTEREST}

The authors declare that there are no conflicts of interests regarding the publication of this manuscript.

\section{REFERENCES}

[1] Brent A., Labuschagne C. Social indicators for sustainable project and technology life cycle management in the process industry. The International Journal of Life Cycle Assessment 2006:11(1):3-15. doi:10.1065/lca2006.01.233

[2] Adams W.M. Green Development: Environment and Sustainability in the Third World. New York: Routhedge, 2009.

[3] Espinosa, A., Walker, J. A Complexity Approach to Sustainability: Theory and Application. London: Imperial College Press, 2011.

[4] Hugo A. Pistikopoulos E.N. Environmentally conscious long-range planning and design of supply chain networks. Journal of Cleaner Production 2009:13(15):1471-1491. doi:10.1016/j.jclepro.2005.04.011

[5] Lenzen M. Primary energy and greenhouse gases embodied in Australian final consumption: An input-output analysis. Energy Policy 1998:26(6):495-506. doi:10.1016/S0301-4215(98)00012-3

[6] Liang S., Zhang T. Urban metabolism in China: achieving dematerialization and decarburization in Suzhou. $J$ Ind Ecol 2011:15(3):420-34.

[7] Duque J., Barbosa-Póvoa A.P., Novais A. Design and planning of sustainable industrial networks: Application to a recovery network of residual products. Industrial \& Engineering Chemistry Research 2010:49(9):4230-4248 doi:10.1021/ie900940h

[8] Hammond A., Adriaanse A., Rodenburg E., Woodward R. Environmental indicators: A systematic approach to measuring and reporting on environmental policy performance in the context of sustainable development. World resources institute, 2007

[9] Gusca J., Fainzilbergs M., Muizniece I. Life cycle assessment of landfill mining project. Energy Procedia 2015:72:322-328. doi:10.1016/j.egypro.2015.06.047

[10] Zhang Y., Liu H., Li YT. et. al. Ecological network analysis of China's societal metabolism. J Environ Manage 2012:93(1):254-63. doi:10.1016/j.jenvman.2011.09.013 
[11] $\mathrm{Xu}$ M. Development of the physical input monetary output model for understanding material flows within ecological-economic systems. J Res Ecol 2010:2(1):123-34. doi:10.3969/j.issn.1674-764x.2010.02.004

[12] Sa-nguanwongthong N. Study of Environmental Costs for the Evaluation of Industrial Development in Thailand. Ph.D. thesis. Bangkok: National Institute of Development Administration, 2013.

[13] Leontief W.W. Input-Output Economics. New York: Oxford University Press, 1986.

[14] Pantavisid S. Natural Resource and Environmental Costs of Good and Service Production via Sustainable Consumption and Production Approach towards Prioritizing the Environmental Management in Thailand. Ph.D. thesis. Bangkok: National Institute of Development Administration, 2012.

[15] Thailand Development Research Institute (TDRI). Prioritizing Environmental Problems with Environmental Costs. Final report prepared the Thailand Health Fund. Bangkok: 2007

[16] Asian Development Bank (ADB). Environment, Climate Change, and Disaster Risk Management. Manila: Asian Development Bank, 2014.

[17] Graabak I., Bakken B., Feilberg N. Zero Emission Building and Conversion Factors between Electricity Consumption and Emissions of Greenhouse Gases in a Long Term Perspective. Environmental and Climate Technologies 2014:13:12-19. 10.2478/rtuect-2014-0002

[18] Ukaga O., Maser C., Reichenbach M. Sustainable Development: Principle Frameworks and Case Studies. London: CRC Press Taylor and Frances Group, 2010.

[19] Repele M., Bazbauers G. Life Cycle Assessment of Renewable Energy Alternatives for Replacement of Natural Gas in Building Material Industry. Energy Procedia 2015:72:127-134. doi:10.1016/j.egypro.2015.06.018

[20] Vigants H., Blumberga D., Veidenbergs I. Demand Side Management in Pellet Production: Internal and External Factors. Environmental and Climate Technologies 2015:14(1):30-35. 10.1515/rtuect-2014-0011

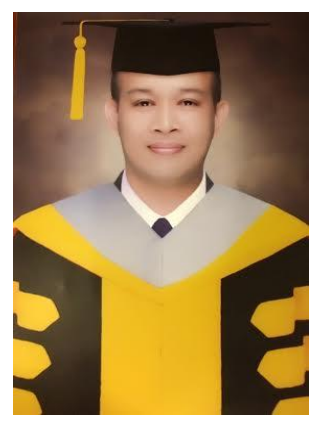

Dr. Pruethsan Sutthichaimethee, Instructor, Institute for Population and Social Research, Mahidol University, Thailand.

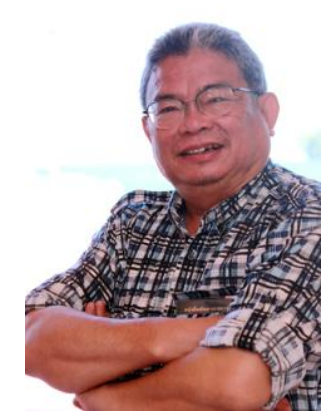

Associate professor Dr. Yothin Sawangdee. Has Ph.D in Sociology (finished The University of North Carolina at Chapel Hill, USA). Bachelor Degree in Political Sciences (Government and Politics) at Ramkhamheang University; Master Degree in Demography at Institute for Population and Social Research at Mahidol University; Master Degree in Sociology at University of North Carolina at Chapel Hill, USA.

Instructor at Institute for Population and Social Research, Mahidol University, Thailand. 